International Journal of

Supply Chain

Management

(IJSCM)

EFFECTS OF BEVERAGE SMUGGLING IN THE SUPPLY CHAIN INDUSTRY: A CASE OF THE COLD CHAIN ZAMBIA LTD

Nyambishi Tatenda Jeffison and Eng. Dr. Kasongo Richard Mwale

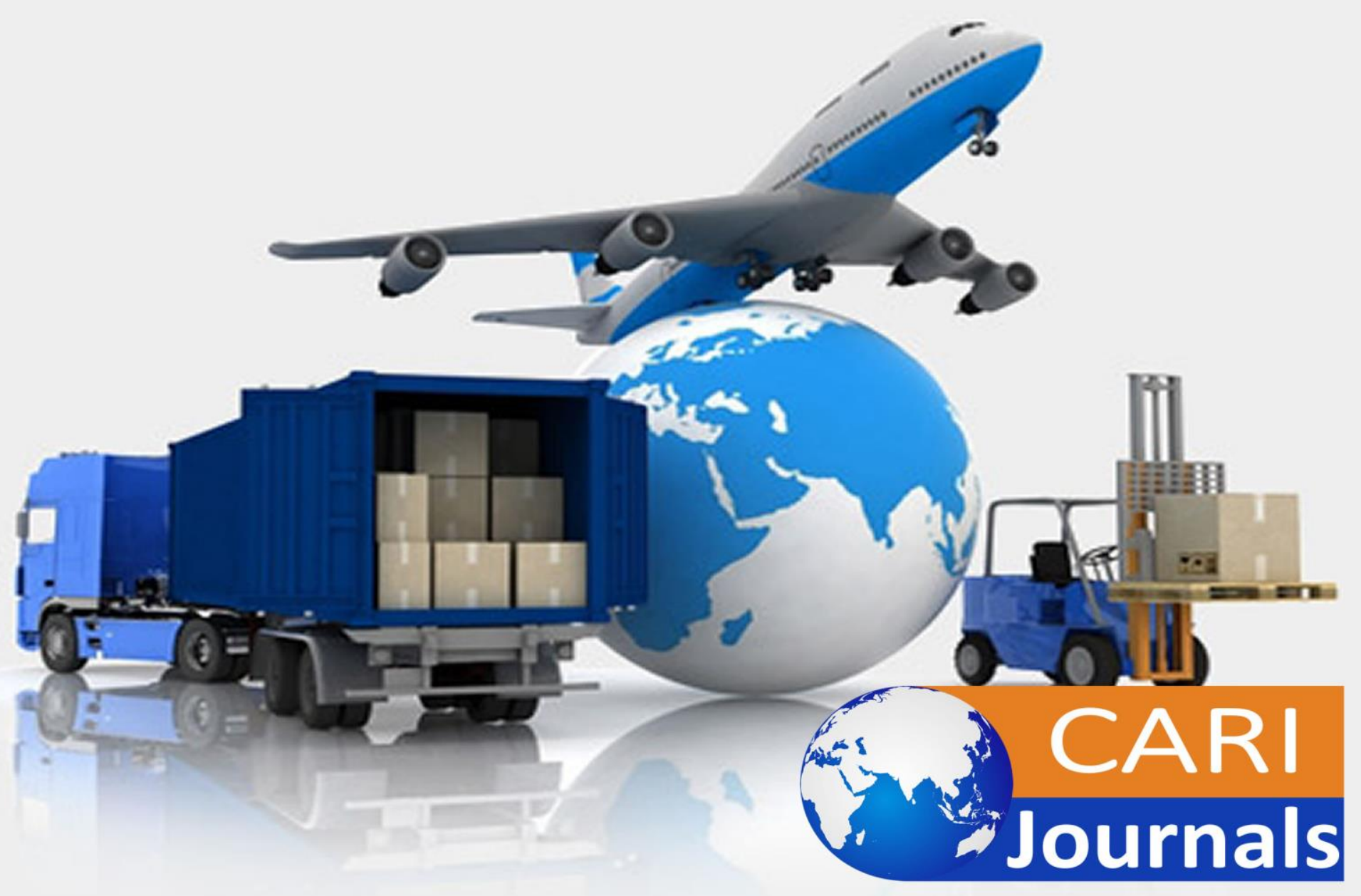




\title{
Effects of Beverage Smuggling in The Supply Chain Industry: A Case of The Cold Chain Zambia Ltd
}

\author{
1*Nyambishi Tatenda Jeffison \\ ${ }^{1}$ Postgraduate student Graduate: School of business, University of Zambia, Lusaka, Zambia \\ *Corresponding Author's Email: tatendanyambishi@gmail.com \\ ${ }^{2}$ Eng. Dr. Kasongo Richard Mwale \\ Lecturer: Graduate School of business, University of Zambia, Lusaka, Zambia
}

\begin{abstract}
Purpose: The aim of the study was to establish strategies that can counter smuggling of beverages and improve business performance for The Cold Chain Zambia ltd. Smuggling poses a threat to the business as it destabilizes the legal industry of supply chain, restrains innovation and investments as well as posing a threat of company closures. Smuggling has caused loss of consumer confidence in buying beverages from Cold Chain Zambia ltd as the products are perceived to be expensive as compared to similar smuggled beverages in the market. The objectives of the study were to determine the extent of the effects of beverage smuggling on the Cold Chain Zambia business performance, to identify strategies which will counter beverage smuggling and to establish strategies that can be used to counter beverage smuggling and improve Cold Chain Zambia business performance.

Methodology: The research design that was used was mixed methods which took the form of exploratory sequential mixed method design. The target population was 80 employees from Cold Chain Zambia ltd which included both general staff and management staff.

Findings: There seems to be no correlation between business performance and strategies to counter beverage smuggling. In this case, H3: There is a significant correlation between the business performance and the perception of strategies to counter beverage smuggling in cold chain supply and was rejected. It was found that there is a negative and significant correlation between beverage smuggling and strategies to counter beverage smuggling on business turnover $(\mathrm{F}=$ 14.339; $\mathrm{p}<0.001)$.

Unique contribution to theory, policy and practice: The researcher recommended that smuggling can be reduced by ensuring the goods are sold at competitive prices to reduce benefit of smuggling, continue with quality control, educate the public on smuggling and how to report and identify smuggling, stiffen law on smuggling in Zambia and review the clearing procedure at all points of entry to fasten the process.
\end{abstract}

Key Words: Beverage, Business Performance, Smuggling, and Counter Strategies. 
International Journal of Supply Chain and Logistics

ISSN 2520-3983 (online)

Vol.4, Issue No.1, pp 13 - 26, 2020

www.carijournals.org

\subsection{INTRODUCTION}

Supply Chain has become an integral part of most businesses globally and is essential to company successes and customer satisfaction. Supply chain management refers to the management of supplying goods and products required by the end customer (John, 2000). In other words, it refers to an organization that manages products that reach an end user. Supply chain affects the day to day lives of people as it leads to the accessibility of goods and services that are required for use (Christopher, 2016).

Supply Chain in the contemporary world reflects the growing emphasis concerning the strategic importance of suppliers (Donlon, 2005). Supplier relationships are gradually shifting from an adversarial approach to a more cooperative approach with the other competitive suppliers. The modern day supplier relationship now include supplier development, partnering ,supplier design involvement, use of full service ,life cycle costing, use of long term supplier contracts and relationships as well strategic cost management.

Supply chain as an industry is multi-faceted and involves supply of various goods. Supply chain management has been becoming increasingly important in competitive business. To compete at the supply chain level, firms must adopt an appropriate supply chain management strategy. The strategy needs to integrate and coordinate throughout the supply chain management strategy. Supply chain management encompasses set of approaches and practices that effectively integrate with suppliers, manufacturers, distributors and customers to improve the long-term business performance and their supply chain (Meindl, 2007).

Through importing of goods, smuggling comes into effect, smuggling can be defined as the secret movement of goods across national borders to avoid customs duties, import or export restrictions (Nduati, 2014). It typically occurs when either the customs duties are high enough to allow a smuggler to make a large profit on the clandestine goods or when there is a strong demand for prohibited goods. Smuggling is the illegal trade in goods to avoid paying customs duties and taxes.

\subsection{Background}

Smuggling as defined by the Zambia Revenue Authority is the secret movement of goods across national borders to avoid customs duties or import or export restrictions. Smuggling includes nondeclaration of goods where no product is declared at port of entry and not being in possession of any legal import documentation can also be considered as outright smuggling. On the other hand, smuggling could take place through legal channels of trade by various means to evade customs duties and other taxes applicable on such goods and products. This is referred to as technical smuggling and such goods are liable for confiscation under section 159 of the Customs and Excise Act. Smuggling is also defined as an illegal method of conducting business ,it is a clandestine activity which involves the importation or exportation of goods by wrong or un lawful means with the objective of evading taxes and any other measures prohibiting or restricting the importation or exportation of such goods (Laurent,2007).

Thompson (2013) asserts that the originality and legitimate product is essential in maintaining the product image and its demand on the market. The legitimate products offer high quality to the consumer whilst on the other hand smuggled goods alter the acceptance of the legitimate goods and in most cases are of poor quality due to handling .Producers and distributors of beverage 
products have in the recent past and until now experiencing a huge influx of smuggled products on the market. The Zambia Police Intellectual Property Unit (2015) estimates to have seized about 2453 assorted beverage products in the past 2 years according to a report published by the Zambia Police press department. The effects therefore of smuggled products on the sales of original and legitimate products in the market have been declining as the smuggled goods are of the same nature and they also come at a very low price.

The Cold Chain Zambia ltd is a distribution company which imports beverages, the company's survival is being threatened due to the smuggling of beverages.The Cold Chain Zambia Ltd is one of the company's that follow due procedure when importing beverages by making sure all rules and regulations are abide to through declaration of goods and paying all relevant customs taxes and fees. However, some importers are involved in illegal activities by evading taxes and creating a grey market whereby similar beverages supplied by The Cold Chain Zambia ltd are smuggled and landed at a lower cost hence becoming subsequently cheap as compared to the beverages supplied by The Cold Chain Zambia.

\subsection{Statement of The Problem}

The Cold Chain Zambia as an importer and distributor of fruit juice beverages has not been spared by the effects of beverage smuggling. Smuggling poses a threat to the business as it destabilizes the legal industry of supply chain, restrains innovation and investments as well as posing a threat of company closures. Companies face unfair competition from smuggling activities, smuggling has greatly affected The Cold Chain Zambia in that smuggled fruit juice beverages have got distorted prices in the market which are far lower than that of The Cold Chain Zambia ltd, the smuggled beverages are relatively cheap and they are leading to the reduction in sales of the beverages that The Cold Chain Zambia supply and also reduction of profits which is used as a measure of business performance. Smuggling has led to the destroying of the local market for beverages that are supplied by The Cold Chain Zambia ltd and the company is slowly becoming less viable in the supply chain industry. This has also caused loss of consumer confidence in buying beverages from Cold Chain Zambia ltd as the products are perceived to be expensive as compared to similar beverages.

Regardless of efforts instituted by government in trying to curb smuggling, it is still rampant in Zambia. There is therefore clearly a need to find permanent solutions and measures that the manufacturers, importers and distributors can also adopt to counter smuggling activities and improve their business performance. 
International Journal of Supply Chain and Logistics

ISSN 2520-3983 (online)

Vol.4, Issue No.1, pp 13 - 26, 2020

www.carijournals.org

\subsection{LITERATURE REVIEW}

Various literature which relates on smuggling, effects of beverage smuggling, business performance and measures that can be taken to counter smuggling were reviewed and these were meant to provide an insight of the previous relevant contributions to the problem.

\subsection{Theoretical Review}

\subsubsection{The Stakeholder Theory}

The stakeholder perspective is an alternative way of understanding how companies and people create value and trade with each other. Freeman (2008) discussed the foundation concepts and implementation of stakeholder management as well as the advantages this approach provides to firms and their managers. The theory points out how managers can create stakeholder oriented control systems by examining some of the important stakeholder-related issues that are worthy of future scholarly and managerial attention in the supply chain industry.

Stakeholders are those parties considered important for the success of a corporation. It includes suppliers, employees, communities, shareholders and managers (Keitany and Moronge, 2013). Donaldson and Preston, (1995), ascribe to the notion that stakeholders are not only essential to the company but to the economy at large. The theory is founded on the tenet that the company's decisions affect the stakeholders.

The theory postulates that agents and stakeholders should operate on ethical terms and while addressing the interest of stakeholders. The illegitimate trade which is smuggling of beverages is not founded on ethics and therefore, impacts negatively on stakeholders. The theory is relevant to the study since it satisfies and ensures that the diverse needs of all stakeholders are well articulated and well represented. This is made possible with established relationships with stakeholders of the firm who include suppliers and customers.

Of importance to this study, through reviewing the stakeholder theory will be the company's competitors. Beverage smuggling is widespread because some competitors are not conducting business in a fair manner and hence resort to unethical methods of doing business. This brings the role the aggressive strategies whereby companies need to come up with such in order to combat unfair competition in the industry.

\subsubsection{Theory of supply chain management}

The theory explicitly explains role of intermediaries, their advantage over direct sales and their roles in setting up prices, cost and setting up competition, (Spulber,1996).The existence of intermediaries creates room for smuggling activities. The principle focus on market competition is not only between goods but also between supply chains delivering the goods and coordinating, quality logistics between suppliers and distributors that becomes critical and marks the success of the supply chain links Jacklick (2005).

The theory of supply chain management stipulates the need to have legal supply chain relationships. Supply chain management hinges upon trust and commitment on the parties involved and hence the presence of trust results in successful supply chain management .Conversely, a lack of trust among supply chain partners has been proven to result in the inefficient and ineffective 
performance of the supply chain as a whole and directly affect the business performance of other firms. Therefore, the theory of supply chain management forms a basis of this research study.

Firms in the supply chain industry have to mitigate the challenges so as to keep their businesses afloat. Some of the challenges are increased cost throughout the supply chain, technology strategy and implementation, shrinkage and theft, smuggling of goods and providing safety and quality goods (Slater, 2006).

\subsection{Conceptual framework}

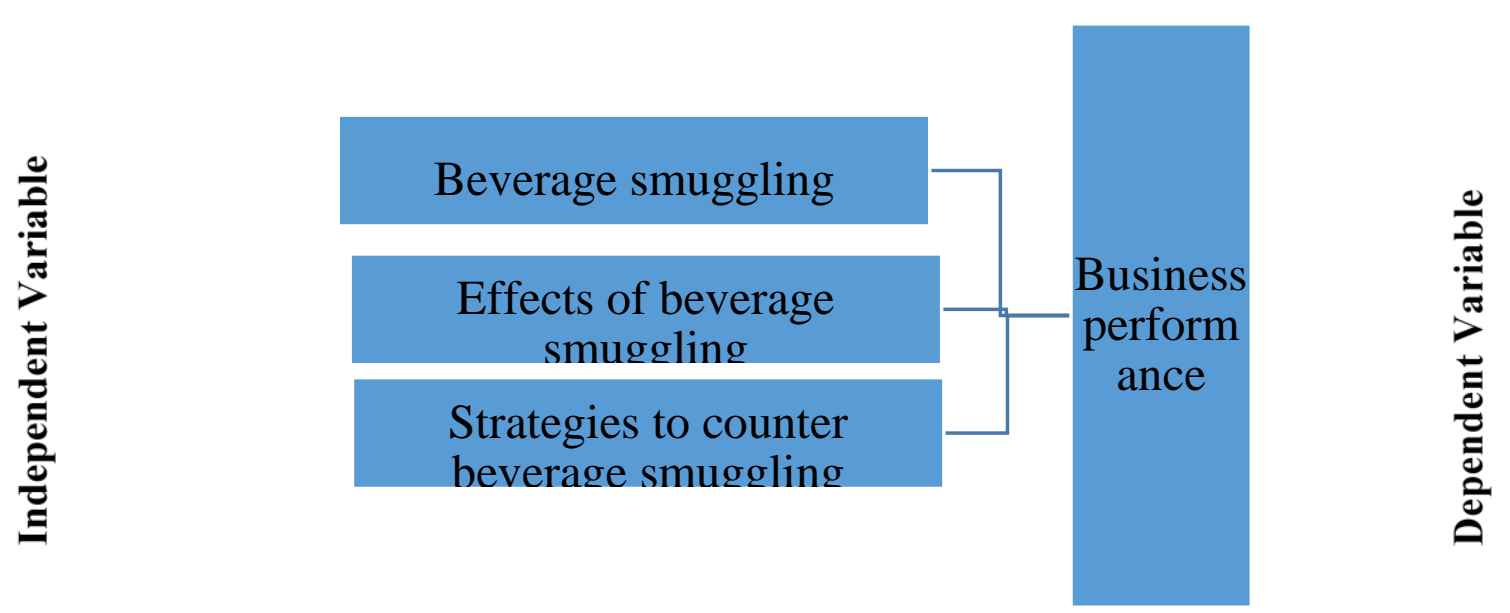

\section{Figure 1: Conceptual framework}

\subsection{Statements of Hypothesis}

Furthermore, the researcher developed the statements of hypothesis as follows:

\subsubsection{Beverage Smuggling}

H0: There is no significant relationship between beverage smuggling and business performance at Cold Chain Zambia.

H1: There is significant relationship between beverage smuggling and business performance at Cold Chain Zambia.

\subsubsection{Effects of beverage Smuggling}

H0: There is no significant relationship between effects of beverage smuggling and Business performance at Cold Chain Zambia.

H1: There is significant relationship between effects of beverage smuggling and Business performance at Cold Chain Zambia.

\subsubsection{Strategies to counter beverage smuggling}

H0: There is no significant relationship between strategies to counter beverage smuggling and business performance at Cold Chain Zambia. 
International Journal of Supply Chain and Logistics

ISSN 2520-3983 (online)

Vol.4, Issue No.1, pp 13 - 26, 2020

www.carijournals.org

H1: There is significant relationship between strategies to counter beverage smuggling and Business performance at Cold Chain Zambia.

\subsection{Operationalization of Conceptual Framework.}

Beverage smuggling is the illegal way of importing beverages through illegal means for many reasons which includes tax avoidance in order to lower the product cost of the product. To this paper, beverage smuggling is the problem which is affecting business performance for The Cold Chain Zambia Ltd. Effects of beverage smuggling: The effects of beverage smuggling have got too many negative consequences on the business performance of companies in the supply chain industry, these effects leads to the dwindling of sales and profits of the legal distributors of the beverages since the product being smuggled will be cheap in the market. Strategies to counter beverage smuggling: Business Strategies are a set of proactive actions on the part of management, for the purpose of enhancing the company's market position and overall performance as well as reactions to unexpected developments and new market conditions (Porter, 1985).The strategies to be employed to counter beverage smuggling will subsequently improve The Cold Chain Zambia business performance.

Business performance is the dependent variable which depends on the effects of beverage smuggling and the strategies to counter beverage smuggling.This is also known as the responding variable and central to the study (Herbrick, 2013).If the effects of beverage smuggling are worked on, business performance will improve and if the strategies to counter beverage smuggling are put in place, the business performance for The Cold Chain Zambia Ltd will improve.

\subsection{Empirical Review}

\subsubsection{Smuggling and its forms}

Smuggling is a fact in societies all over the world. In essence it is an activity that is used to earn income from carrying illegal activities. Smuggling affects the economy and the world at large in many ways. The main reason for smuggling is tax evasion, which deprives the government of its legitimate revenues (Harry,2005). Therefore, a decline in smuggling will increase the tax revenues of the government. From the perspective of criminal law, smuggling of goods as an illegal economic phenomenon is opposite to the social order. Smuggling can be prosecuted and punished according to the relevant laws. Since the smuggling is perceived as a social risk, it also negatively affects economy, it will certainly reduce the social security. Smuggling of goods has social, political, cultural and, more importantly, economic consequences. Harry (2005) states that from economic point of view, smuggling deviates economics from the safe path and causes formation of the underground economy and decline in GDP and investment. In the short term, smuggling is considered as a way to escape poverty and unemployment through false job creation. However, these activities will not lead to production, so smuggling of goods will exacerbate poverty in the long terms through weakening production fundamentals.

The methods of smuggling are as many and varied as the smuggler has imagination to dream up. According to Thomas (2005) they use outright avoidance of customs borders, under declaration of goods, undervaluation of goods, mis calculation of goods, falsification of documents, mis classification of country of origin, bribery and concealment. 
International Journal of Supply Chain and Logistics

ISSN 2520-3983 (online)

Vol.4, Issue No.1, pp 13 - 26, 2020

www.carijournals.org

\subsubsection{Effects of smuggling on businesses in the beverage industry.}

Effects of beverage smuggling includes distortion of Market Prices whereby beverages which are smuggled into the country are often a lot cheaper than the goods brought onto market through the right procedures. Smuggling therefore deprives traders of free competition. Secondly there is collapse of local industries. A country achieves better economic growth by developing its own industrial base. Smuggling under cuts prices of the locally manufactured goods thus destroying the market for local products. This leads to collapse of local industries. According to (Phillip 2006) smuggling affects domestic consumption with supply of cheap products.

Unemployment is when there is unfair competition in the market, compounded by the collapsing of industries, the labor market which is the employment base is eroded. Many professional skilled and unskilled personnel remain jobless. Undermine firms' investments which are often substantial in developing well managed distribution networks. Innovation in the form of conception of new ideas for development of new products or processes and experimentation, has been recognised widely as an important driver of economic growth. Innovators protect their ideas through patents, copyrights, design rights and trademarks. Without adequate protection of these intellectual property rights, the incentive to develop new ideas and products is reduced, thereby weakening the innovation process. In industries where product development requires significant investment and innovation, smuggling of counterfeit product impairs investments and innovation by undermining the efforts of innovators and discouraging them from further research and development, which ultimately hampers overall growth of the economy.

\subsubsection{Business Performance}

Business performance as defined by Lindsey (2008) is an approach which looks at the business as whole instead of a division within a business. Business performance entails reviewing the overall business and determining how the business can better its goals. This requires the alignment of strategic and operational objectives and the business' set of activities in order to manage performance. Business performance relates to efficiency, effectiveness, financial viability and relevance. Effectiveness brings out the peculiar abilities which organizations must embrace in in ensuring attainment of their missions. Efficiency is described as the unit cost of output which is much less than the input leaving no alternative option through which the input can be reduced for the same amount of output (Machuki, 2011). Financial viability on the other hand has been defined as a firm's ability to harness its financial resources which are its inflow of financial resources that must be greater than the outflow. Ricardo (2001), defined business performance as the ability of a firm to maximize strengths to overcome its weakness to neutralize its threats and take advantage of its opportunities.

\subsubsection{Competitive strategies to counter beverage smuggling}

There have been many articles written on the legal, health and most importantly economic problems caused by smuggling of beverages around the globe. Various strategies have been advised by many researchers in the quest to protect the legal supply chain industry.

The strategies include surveillance strategies in China. Finn (2008), suggested some strategies that can counter beverage smuggling under the theme 'fighting beverage smugglings. In this case study, author suggested 3 strategies that can be used Legal method, Surveillances and 
International Journal of Supply Chain and Logistics

ISSN 2520-3983 (online)

Vol.4, Issue No.1, pp 13 - 26, 2020

www.carijournals.org

upgrading packages. Legal method is a proactive strategy adopted by the Pepsi cola company in China against smuggled goods, under surveillance, Coke company in China which was facing a lot of smuggled similar beverages would employ surveillance strategies whereby they would connect directly to its consumers and retail customers and by so doing the companies would close the gaps for any smuggled goods to be distributed to its customers (Finn,2008).

Protection strategies in Canada, according to Tidd (2008), states that a company must adopt protection strategies in order to counter beverage smuggling. In Canada, the biggest beverage supplier for soft drinks which is Big 8 has not been spared by the effects of smuggling and huge financial losses as the smuggled beverages which found their way into the Canadian market were of cheap value. Protection strategies included both external and internal tactics to protect the brands. Internal tactics are related to changes in existing packaging, color combination or a logo and the change in packaging, color combination and logo must be different, complex and difficult to copy.

\subsubsection{Knowledge Gap}

Countering beverage smuggling at company level is not clearly brought out in the literature review. There are little efforts which have been done by companies alone in developing strategies to stay competitive in the face of beverage smuggling. Most strategies which have been pursued and brought out by researchers have got more to do with strategies pursued at industry level and national level. There has been more of strategies employed by government agencies such as revenue boards, pressure groups and industry groups in the fight against smuggling. Little literature has been pursued to counter smuggling but most of the literature has been advanced to stop smuggling. Very little has been done to help companies affected by smuggling to come up strategies to counter smuggling and improve business performance .Most literature leaves out strategies that can be employed to improve business performance of companies in the supply chain industry

\subsection{METHODOLOGY}

This study was carried out within the framework of a mixed methods research design employing the exploratory sequential design. The mixed methods approach assisted this researcher in having a rich, detailed and often emotionally driven and insights based on the personal views of the questionnaires which were conducted at the Cold Chain Zambia ltd within the setting of the activities and operations of the Cold Chain Zambia ltd which operates in a supply chain industry.

The quantitative part therefore gave us a broader robust view, based on hard statistics for example how many employees understand beverage smuggling and its effects on the business performance of The Cold Chain Zambia Ltd. The qualitative part provided depth and detail of the effects of beverage smuggling and also business performance for The Cold Chain Zambia ltd. The population of interest in the study was top level management, Logistics team, marketing team, sales team and all Cold Chain Zambia employees who are pertinent to the beverage smuggling, function and decision making concerning effects of beverage smuggling on the Cold Chain Zambia business. This group consists of 400 individuals. The sample respondents of interest in this study was top level management, Logistics team, Marketing team, Sales team and all Cold Chain Zambia 
employees who are pertinent to the effects of beverage smuggling to The Cold Chain Zambia ltd's business. The researcher used purposive sampling technique to come up with the sample size. A sample size of 80 respondents was drawn from the population

Research data for the study was collected using primary sources. Primary data was collected using a self-administered structured and unstructured questionnaire. The questionnaires were distributed to the respondents directly by the researcher. Research data was analyzed using descriptive statistics and for ascertaining association between variables. The researcher utilized Statistical Package for Social Sciences (SPSS) as the main descriptive statistical tool to analyze the data and determine the extent of relationships between the independent and dependent variables. The results of the processed data was presented using percentages, means, standard deviations, frequencies, pie charts and tables for easy understanding.

\subsection{DATA ANALYSIS, PRESENTATION AND DISCUSSION}

\subsection{Descriptive results}

This chapter provides a detailed analysis of the variables to do with the effects of beverage smuggling on business performance in the supply chain industry at Cold Chain Zambia LTD. The chapter also provides an analysis of the suggested solutions. The research utilized structured questionnaires to collect primary data. Utilizing a combination of quantitative and qualitative methods made the research more reliable and useful.

Table 1: Gender of respondents

\begin{tabular}{lcccc}
\hline Statements & Frequency & Percent & Valid Percent & Cumulative Percent \\
\hline Male & 47 & 58.8 & 58.8 & 58.8 \\
Female & 33 & 41.3 & 41.3 & 100 \\
Total & $\mathbf{8 0}$ & $\mathbf{1 0 0}$ & $\mathbf{1 0 0}$ & \\
\hline
\end{tabular}

Source: (Research data, 2020)

The table above shows that the majority of respondents amongst the participants were males which was $58.8 \%$, while $41.3 \%$ were females. From the results, the study had more male respondents than females.

Table 2: Understanding of beverage smuggling importance to employees.

\begin{tabular}{lcccc}
\hline Statements & Frequency & Percent & Valid Percent Cumulative Percent \\
\hline Strongly agree & 19 & 23.8 & 23.8 & 23.8 \\
Agree & 41 & 51.2 & 51.2 & 75 \\
No answer & 13 & 16.3 & 16.3 & 91.3 \\
Disagree & 3 & 3.8 & 3.8 & 95 \\
Strongly disagree & 4 & 5 & 5 & 100 \\
Total & $\mathbf{8 0}$ & $\mathbf{1 0 0}$ & $\mathbf{1 0 0}$ & \\
\hline
\end{tabular}

Source: (Research data, 2020) 
The table above shows the importance of employees understanding the smuggling of beverage, $42.5 \%$ majority of the respondents strongly agreed to this statement, $38.8 \%$ of the respondents agreed to this statement, $10.0 \%$ of the respondents did not have an answer $4.0 \%$ of the respondents disagreed about the importance of employees understanding the smuggling of beverage and 3.8\% strongly disagreed to the importance of employees understanding the smuggling of beverage. The results show that most of the respondents were aware of the importance of employees understanding the smuggling of beverage and how it might affect them.

\subsection{Inferential results}

Table 3. Correlation Results of Business Performance and Effects of beverage smuggling

\begin{tabular}{|c|c|c|c|}
\hline Correlations & & $\begin{array}{c}\text { Business } \\
\text { performance }\end{array}$ & $\begin{array}{c}\text { Effects of beverage } \\
\text { smuggling }\end{array}$ \\
\hline & Pearson & & \\
\hline & Correlation & 1 &,$- 573 * *$ \\
\hline & Sig. (2-tailed) & & 0 \\
\hline \multirow[t]{3}{*}{ Business performance } & $\mathrm{N}$ & 80 & 80 \\
\hline & Pearson & & \\
\hline & Correlation & $-.573 * *$ & 1 \\
\hline \multirow{2}{*}{$\begin{array}{l}\text { Effects of beverage } \\
\text { smuggling }\end{array}$} & Sig. (2-tailed) & 0 & \\
\hline & $\mathrm{N}$ & 80 & 80 \\
\hline
\end{tabular}

Source: (Research data, 2020)

Table shows that there is a negative and significant moderate correlation between business performance and effects of beverage smuggling. (Pearson Correlation coefficient $=-0.573$. As a result of this correlation analysis, H2: There is a significant correlation between the business performance and the perception of effects of beverage smuggling in the cold chain supply and was accepted.

Table 4: Correlation Results of Business performance and Strategies to counter Beverage Smuggling

\begin{tabular}{|c|c|c|c|}
\hline Correlations & & $\begin{array}{l}\text { Business } \\
\text { performance }\end{array}$ & $\begin{array}{l}\text { Strategies to counter } \\
\text { beverage smuggling }\end{array}$ \\
\hline \multirow{5}{*}{ Business Performance } & Pearson & & \\
\hline & Correlation & 1 & $-.060 * *$ \\
\hline & Sig. (2-tailed) & & 0.626 \\
\hline & $\mathrm{N}$ & 80 & 80 \\
\hline & Pearson & & \\
\hline \multirow{3}{*}{$\begin{array}{l}\text { Strategies to counter } \\
\text { beverage smuggling }\end{array}$} & Correlation & $-.060 * *$ & 1 \\
\hline & $\begin{array}{l}\text { Sig. } \\
\text { tailed })\end{array}$ & 0.526 & \\
\hline & $\mathrm{N}$ & 80 & 80 \\
\hline
\end{tabular}

Source: (Research data, 2020) 
International Journal of Supply Chain and Logistics

ISSN 2520-3983 (online)

Vol.4, Issue No.1, pp 13 - 26, 2020

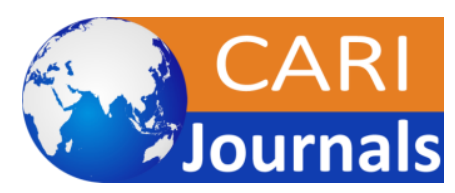

www.carijournals.org

As Table shows that there seems to be no correlation between business performance and strategies to counter beverage smuggling. In this case, H3: There is a significant correlation between the business performance and the perception of strategies to counter beverage smuggling in cold chain supply and was refused.

Table 5: Extent of the effects of beverage smuggling on business performance

\begin{tabular}{lcccc}
\hline Statements & Frequency & Percent & Valid Percent & Cumulative Percent \\
\hline Strongly agree & 25 & 31.3 & 31.6 & 31.6 \\
Agree & 34 & 42.5 & 43 & 74.7 \\
No answer & 14 & 17.5 & 17.7 & 92.4 \\
Disagree & 4 & 5 & 5.1 & 97.5 \\
Strongly disagree & 2 & 2.5 & 2.5 & 100 \\
Total & $\mathbf{7 9}$ & $\mathbf{9 8 . 8}$ & $\mathbf{1 0 0}$ & \\
\hline Missing System & 1 & 1.3 & & \\
Total & $\mathbf{8 0}$ & $\mathbf{1 0 0}$ & & \\
\hline
\end{tabular}

Source: (Research data, 2020)

The results whether beverage smuggling affects the business performance of the Cold Chain Zambia showed that $42.5 \%$ of the respondents agreed beverage smuggling affects business performance, $31.3 \%$ of the respondents strongly agreed that beverage smuggling affects business performance, $17.5 \%$ of the respondents did not have an answer, $5.0 \%$ of the respondents disagreed beverage smuggling affects business performance and $2.5 \%$ of the respondents strongly disagreed that beverage smuggling affects business performance. From the results it was observed that the respondents understood the effects smuggling has on Cold Chain Zambia if not controlled or completely reduced

The respondents further indicated that loss of revenue, loss of customer base, loss of employment due to company closure and poor tax revenue collection by ZRA. The findings show that smugglings do have an effect of the performance of Cold Chain Zambia.

Table 6: Identify strategies which will counter beverage smuggling

\begin{tabular}{lcccc}
\hline Statements & Frequency & Percent & Valid Percent Cumulative Percent \\
\hline Strongly agree & 34 & 42.5 & 42.5 & 42.5 \\
Agree & 31 & 38.8 & 38.8 & 81.3 \\
No answer & 8 & 10 & 10 & 91.3 \\
Disagree & 4 & 5 & 5 & 96.3 \\
Strongly disagree & 3 & 3.8 & 3.8 & 100 \\
Total & $\mathbf{8 0}$ & $\mathbf{1 0 0}$ & $\mathbf{1 0 0}$ & \\
\hline
\end{tabular}

\section{Source: (Research data, 2020)}

The study sought to find out the importance of employees understanding beverage smuggling. From the results $42.5 \%$ majority of the respondents strongly agreed that it is important for employees to understand beverage smuggling, $38.8 \%$ of the respondents also agreed that it is 
important for employees to understand beverage smuggling, $10.0 \%$ of the respondents did not have an answer $4.0 \%$ of the respondents disagreed about the importance of employees understanding the smuggling of beverage and $3.8 \%$ strongly disagreed to the importance of employees understanding the smuggling of beverage. The results show that most of the respondents were aware of the importance of employees understanding the smuggling of beverage and how it might affect them. It is important for employees to know and understanding smuggling for them to participate in the fight against smuggling and improve the performance of Cold Chain Zambia beverages on the market. This study can conclude that one of the main causes of smuggling in border cities is poverty and unemployment due to the increase in labor supply and decrease of demand for labor in the formal sector is causing it.

Table 7: How can strategies be enhanced and improve The Cold Chain Zambia business performance.

\begin{tabular}{lcccc}
\hline Statements & Frequency & Percent & Valid Percent & Cumulative Percent \\
\hline Strongly agree & 5 & 6.3 & 6.4 & 6.4 \\
Agree & 21 & 26.3 & 26.9 & 33.3 \\
No answer & 33 & 41.3 & 42.3 & 75.6 \\
Disagree & 15 & 18.8 & 19.2 & 94.9 \\
Strongly disagree & 4 & 5 & 5.1 & 100 \\
Total & $\mathbf{7 8}$ & $\mathbf{9 7 . 5}$ & $\mathbf{1 0 0}$ & \\
\hline Missing System & 2 & 2.5 & & \\
Total & $\mathbf{8 0}$ & $\mathbf{1 0 0}$ & & \\
\hline
\end{tabular}

Source: (Research data, 2020)

The study sought find out whether there is a plan to advance the strategies of countering beverage smuggling, $6.3 \%$ of the respondents agreed that there is a plan to advance strategies of countering beverage smuggling, $26.3 \%$ of the respondents strongly agreed that there is a plan to advance strategies of countering beverage smuggling, $41.3 \%$ of the respondents did not have an answer, $18.8 \%$ of the respondents disagreed that there is a plan to advance strategies of countering beverage smuggling, and $5.0 \%$ of the respondents strongly disagreed that there is a plan to advance strategies of countering beverage smuggling. The respondents further indicated that the company should carry out periodical market survey and act as a whistle-blower, reduce prices of beverages, actively get involved in strategies to identify smuggling rings and reporting to the authorities.

\subsection{CONCLUSION AND RECOMMENDATION}

\subsection{Conclusion}

The aim of the study was to establish strategies that can counter smuggling of beverages and improve business performance for The Cold Chain Zambia ltd. Smuggling poses a threat to the business as it destabilizes the legal industry of supply chain, restrains innovation and investments as well as posing a threat of company closures. This has also caused loss of consumer confidence in buying beverages from Cold Chain Zambia ltd as the products are perceived to be expensive as compared to similar beverages. 
It was concluded that the causes of smuggling included smugglers attempt to evade tax, smugglers endeavor to make quick money by smuggling cheap commodities on the market, high duty, high tax ratios and customs, availability of market for smuggled goods, high demand on the market for that particular brand and also complicated import procedures such as permits for import must be not be more than one permitted company. The study also revealed that lack of nationalism, ignorance and greedy for wealth trying to get rich through tax evasion, low landed costs, duration of time being cleared at the border and high transport cost as causes of smuggling.

From the results it was observed that the respondents understood the effects smuggling has on Cold Chain Zambia if not controlled or completely reduced. On the effects of beverage smuggling the study concluded that it reduces and slowdown sales, poor sales, loss of business, reduces profit margins, the company encounters losses due to flooding of beverages on the markets as a result of low prices and demand for Cold chain beverages reduces. The study further indicated that loss of revenue, loss of customer base, loss of employment due to company closure and poor tax revenue collection by ZRA.

From the findings on the strategies it was revealed that the company should carry out periodical market survey and act as a whistle-blower, reduce prices of beverages, actively get involved in strategies to identify smuggling rings and reporting to the authorities.

The study also suggested that smuggling can be reduced by ensuring the goods are sold at competitive prices to reduce benefit of smuggling, put people who are qualified and professional to operate at boarders and prosecute offenders, continue with quality control, and educated the public on smuggling and how to report and identify smuggling.

\subsection{Recommendation}

Based on the findings, the study recommended the following:

$\checkmark$ The Cold Chain Zambia ltd should carry out market surveys

$\checkmark$ The Cold Chain Zambia Ltd should develop product differentiation mechanisms

$\checkmark$ The Cold Chain Zambia and the distribution industry should advocate for stiffening of laws on smuggling in Zambia

$\checkmark$ All Cold Chain Zambia ltd employee involvement in the fight against smuggling.

$\checkmark$ Sensitizing the public on smuggling and how to report smuggling activities through the Zambia Revenue Authority

\section{REFERENCES}

Christopher,A.(2016). Logistics and Supply Chain Management. New York,USA.Pearson Education Press.

Doll,M.B(2017) . Strategic management. An empirical investigation of selected strategy variables on firms' performance. A study of supply chain management in large private manufacturing companies in Kenya. Prime journals, 9-18

Donaldson, T., \& Preston, L. E. (1995). The stakeholder theory of the corporation: Concepts, evidence, and implications. Academy of management Review, 20(1), 65-91. 
International Journal of Supply Chain and Logistics

ISSN 2520-3983 (online)

Vol.4, Issue No.1, pp 13 - 26, 2020

$\underline{\text { www.carijournals.org }}$

Donlon, M. (2005). The moderating effect of group decision making. Stockholm school of economics.

John,S.K (2000). Corporate governance and firm performance. Evidence from Malaysia public listed companies. University of Pittsburg.

Laurent. T., L. (2013). Consumption prices of counterfeit goods in the Italian context, journal of brand management. The quarterly journal of economics. Vol,103 Issue 1 pp 79-100.

Sanda, A., Mikailu, A., \& Garba, T. (2005). Corporate governance mechanisms and firm financial performance in Nigeria: African Economic Research Consortium, Research Paper, 149.

McClellan, W. S. (2013). "Smuggling in the American Colonies" (Book Review). American Academy of Political and Social Science 47:282.

Meindl,P.(2015).Supply Chain Management: Strategy, Planning and Operation (6 $6^{\text {th }}$ ed). New York,USA.Pearson Education Press.

Nduati,C.W.(2014). Measures That Can Be Taken to Fight Smuggling in Kenya. (Doctoral Dissertation,United States International University-Africa)

Noble,H.K( 2015). Consumer accomplices in product smuggling. A review of the beverages smuggling in the North of America. Oxford Press.

Pellisier, G. (2007). Research Methods for beginners. An insight. Singapore. John Wiley and sons.

Philips. (2006) Smuggling: A History 1970-1990. Great Britain: David-And-Charles-Publishers.

Ricardo, B. N (2001). Board meeting frequency and Firm performance. Great Britain: David-AndCharles-Publishers.

Slater, K. (2006). Scarcity effects on Value. A Quantitative Review of the commodity theory literature. Washington DC: American Council on Education.

Tan, K. C. (2001). A framework of supply chain management literature. European Journal of Purchasing \& Supply Management, 7(1), 39-48.

Thomas, K, L. (2005). Effects of beverage smuggling on the image of legal brands: An empirical study from the customer perspective. Journal of Brand management Vol 18. Issue 2, pp 159-173.

Thompson, P.A. (2013) Consumer concern, knowledge, and attitude toward renewable energy: an application of the reasoned action theory. New York Press

Turnbull, M, H. (2002). The role of research objectives in modern day research methods. Blackwell publishing company. 